\title{
Connotation of "Belonging-Identity" and contemporary appeal under political confucianism
}

\author{
Dai Zhicheng ${ }^{1}$ D
}

Received: 10 July 2020 / Revised: 12 September 2020 / Accepted: 12 September 2020 /

Published online: 12 November 2020

(C) The Author(s) 2020

\begin{abstract}
The politicization of Confucianism has always been an important dimension to the practice of Confucian realistic values. Strengthening the concept of national identity with Confucianism can maintain the stable order of the country, then realize the enlightenment of social ethics and promote democratic political reform. Yet, Confucianism does not have a specific way to interpret and realize national identity in its cultural connotation. Instead, it shows some meanings of "belonging-identity" in the relationship among individuals, society, and the country. The key point of Confucian "belonging-identity" is its moral nature. We should take the "Supreme goodness" of Confucianism into actualization, socialization, politicization to re-examine and construct an effective mechanism of national identity. Also, Confucianism belongs not only to China. We can apply the Confucian "belongingidentity" system into other Asian countries with similar cultures to realize harmonious relations among individuals, families, and countries. National identity is more a kind of sense, but if we use it in rational political philosophy, such as Confucianism, it can promote the development of democracy of a country.
\end{abstract}

Keywords Political confucianism $\cdot$ Identity $\cdot$ Belonging $\cdot$ Practice

Dai Zhicheng

daizhicheng9@hotmail.com

1 Institute of East Asian Studies, Faculty of Arts and Humanities, University of Cologne,

Cologne, Germany 


\section{Introduction}

The interpretation of the relationship between "belonging" and "identity" in Confucianism is for how to use social belonging, national identity, and national concepts to maintain the stable ruling order of the country. Confucianism belongs to the ruling art of emperors. However, with the continuous development of contemporary democratic politics, both individuals and social development have new demands for national identity. Confucian national "belonging-identity" needs to redefine the various relationships in the national rule, especially for the relationship between individuals and society, and bring "individual's belonging to the family and society" into the national management order, to better guide the effects of national identity for personal, social and national development.

\section{The purpose and meaning of the shift from "belonging" to "identity" under political confucianism}

\section{Justification (正名 Zhengming) realizes the legitimacy of national rule and belonging order by identification}

The purpose of political Confucianism is to solve the problems of state governance from the perspective of the ruler's governance. If political Confucianism is to achieve the effective operation of the state system and social development, it is acceptable. National identity, as an important part of maintaining the ruling order, represents the individual's sense of "belonging-identity" to society and the state. This is the foundation of social and state stability for the ruling order. Individual identification of the state reveals respect and recognition to the rationality and legitimacy of the country's political system. The ruler needs to use the national "belonging" and "identity" under political Confucianism to achieve the "justification" (正 名 Zhengming) of his rule, to maintain "the order of ruling time and ruling position” (时位秩序 shiweizhixu). “ruling position” (时位 Shiwei) represents a period of the rule and the certainty. However, the ruler wants to use the "justification" (正 名 zhengming) to strengthen the long-term nature of the rule and the concreteness of the rule (refer to territories, people, etc.). From the views of Confucius (孔子), the rationality of political power can achieve "trust from the people" (民信之 minxin$z h i)$. This is also procedural justice in which the people recognize the political power for democracy. “irregular names are inconsistent” (名不正则言不顺 mingbuzhengzeyanbushun) shows that the legitimacy of political power needs visible systems and procedures to achieve people's submission. Confucius (孔子) regards "ritual and music" (礼乐 liyue) as the core of “justification” (正名 zhengming), because "ritual and music" (礼乐 liyue) represents the traditional system and order. Strengthening “justification" (正名 zhengming) with national "belonging-identity" can achieve the people's adherence to the system. Placing "ritual" (礼 $l i$ ) in "loyalty" (忠zhong) also ensures that an individual's identification with the political system is equivalent to his identification with the state (Bell 2014). “Justification” (正名 zhengming) 
establishes the "ruling position" (时位 shiwei) of individuals, society, and nations with a stable order of keeping one's position (守其位 shouqiwei) and respecting one's position (尊其位 zunqiwei). In such a “golden mean” (中庸 zhongyong) way, individuals will transform their sense of belongings and identifications of the political order into the order of life, and the ruler will constantly strengthen the people's observance of order.

\section{Enlightenment (教化 Jiaohua) promotes ethical education under the social belonging system with identification}

National identity is for the enlightenment of social ethics and morals, then strengthening the close relationship between individuals and the state with moral power. Political Confucianism emphasizes maintaining the system of political domination, but in different periods, the contents and means of enlightenment are different. The pre-Qin (先秦 xianqin) Confucians point out content and ultimate purpose of enlightenment are to make the world more public than the monarchy's autocracy, but it should first maintain the tradition of "ritual and music" (礼乐 liyue). In the later practice of political Confucianism, Dong Zhongshu (董仲舒) emphasizes the use of moral enlightenment to consolidate the ruling order of the monarch without caring for the interests of people. As ethics and moral enlightenment of Confucianism can contribute to political domination, the ruler takes social ethics and moral enlightenment as priorities in the governing system. However, such saint politics is contrary to the "enlightenment" (教化 jiaohua) under traditional "ritual and music" (礼 乐 liyue). And it is impossible to realize the enlightenment of social ethics without democratic meaning. Promoting moral ethics with political ethics has prime requirements for rulers with govern-ability, moral behavior, and democratic practice. However, "Golden mean" (中庸 zhongyong) of Confucianism cannot truly achieve the development of moral ethics under political ethics. The practice of moral ethics is useless but to speed up the decline of the rule of the emperor, as the enlightenment of the people's ethics will inevitably lead to the desire for individual rights that cannot exist in such a ruling order. Confucians suppose ethics and morals are the only things in politics, ignoring the rationality of political rule, so they create "humanity" (人道 rendao). Confucians believe “nature" (天性 tianxing) and "natural ways" (天 道 tiandao) can realize “golden mean" (中庸 zhongyong) in the individual's interest and social interests (Ames 2011), to maintain the balance between the individual and the society. Therefore, the sense of political belonging or political identity has become a moral pursuit of how individuals deal with relationships with society.

\section{Contingency (权变 quanbian) deepens the influence of identity on the political practice of "belonging"}

The dynamic balance of “time” (时 shi) and “power” (权 quan) under the "golden mean" (中庸 zhongyong) transforms psychological Confucianism to political Confucianism. The combination of “time” (时 shi) and “power” (权 quan) requires 
individuals to consider the actual situation within morality when making trade-offs and choices. Mencius considers “power" (权 quan) as an extension of "ritual” (礼 $l i$ ). “ritual” (礼 li) means “how-to", and “power” (权 quan) means “promising”. Xunzi ( 荀子) combines “power” (权 quan) with political order and makes "balanced using of power and practice” (权物称用 quanwuchenyong) in “acknowledged system” ( 知明制度 zhimingzhidu), realizing variable and suitable political use of "power" ( 权quan). So Xunzi (荀子) emphasizes the restrictions on “power” (权 quan) by “virtue and morality” (道义 daoyi). Mencius values “emotional nature” (情性qingxing) and Xunzi (荀子) values “rational nature” (知性 zhixing). However, Xunzi (荀子) deserts "benevolence" (仁性 renxing) in political rule, making "time changing" ( 时变 shibian) of “ritual” (礼li) far away from “suit time” (时中 shizhong). Under the political rule, Confucians advocate the equality and interaction of "benevolent" (仁道 rendao) and “power in the time" (时权 shiquan), highlighting the relationship between the power and obligation of the rule. If the "power in the time"(时权 shiquan) expands, the "benevolence"(仁道 rendao) will change, ensuring a dynamic balance between the “power” (权 quan) and the “Dao” (道). Ruling order should follow the "Dao" of the world. A ruler should "use power by the Dao" (持道用 权 chiquanyongdao). And in some extreme cases, people can use the "Dao" (道) to cut down the "power" (权 quan) and overthrow the rule of the emperor. Both the ruler or the people should use "benevolence" (仁道 rendao) to design the identity to political rule and the country. Confucius (孔子 kongzi) values “time” (时 shi) and puts "benevolence" (仁道 rendao) in the "power in the time” (时权 shiquan) to maintain the ruler's position and the social order. The pursuit of "goodness" ( 善 shan) in Confucianism under the political rule is dynamic. Confucians believe that “contingency” (权变 quanbian) should develop with time and circumstances to achieve "supreme goodness" (至善 zhishan) of political order and keep personal natural life under the mean of "neutrality" (中庸 zhongyong) and "neutralization" ( 中和 zhonghe). So, individuals transforming from "belonging" to "identity" in the political ruling order ensures the "benevolence" (仁道 rendao) in politics, as "time changing” (时变 shibian) creates “contingency” (权变 quanbian).

\section{The definition and choice of personal social relations under the confucian "belonging-identity" system}

\section{Transformation from "Filial Piety” (孝 xiao) to “Loyalty” (忠 zhong) is the socialization of personal existence}

Confucian morality concentrates on the ethical relationship among people, which does not mean that it weakens or ignores social relationships in a political environment. Confucianism emphasizes that when there are people, there is a home, and when there are homes, there is a country. A home is a basic unit of the country, and it is also fundamental. However, Confucians attach too much importance to family ethics and family concepts. Ignoring national society will cause individuals to lack the concept of a state. Some Confucians believe that individuals should integrate 
their responsibilities to society and the world into the ethics of families to achieve social harmony.

Mencius (孟子 mengzi) says, "take other family’s elders and children as mine" ( 老吾老以及人之老, 幼吾幼以及人之幼 lao wu lao yi ji ren zh ilao, you wu you yi ji ren zhi you), which shows that the way of personal caring for family members should be like the way to other people in society, making family ethics turn into social ethics. Confucius (孔子) believes that individuals' "supreme goodness" (至 善 zhishan) should serve society because it can bring stability to society. However, Confucian personal caring for society is not equal to the country's caring for the people because politics is hierarchical. When an individual's obligation to the family conflicts with his obligation to the state, the individual should choose the family. The national "belonging-identity" must abide by family identity, which roots in the individual's powerful sense of belonging to the family. This is the basic ethics of society. Nationalism emphasizes the public interests, for protecting national territory or loyalty to the people, but it needs to follow family interests first. When public interests conflict with family interests, it will inevitably cause significant damage to family and social ethics, and it will destroy Chinese traditional moral and ethical order. As individuals and families exist in a social and political environment, they need to make corresponding compulsory commitments for social development, to bring external environmental protection for family development. The individual's commitment to the family needs to develop into commitment and recognition to the state. And individuals and families need to take commitment obligations for protecting their rights. This is an invisible contract between the family and the state. The degree of the family's moral ethics determines the degree of the individual's commitment and identity to the family, society, and the state. Correspondingly, those who do not have the concept of family's ethics must not have the concept to the state, let alone national identity. Liang Qichao (梁启超) and Sun Yat-sen (子小中山) attach great importance to the role of family and family's ethics in society. Confucians say that the individual's obligations to the family and compliance with the family's moral integrity are not necessarily the same as the individual's contribution and identification to the society and the country. However, to a certain extent, the relationship between the individual and the family is proportional to the relationship between the individual and the country.

\section{Political identity and cultural identity under individual rational choice}

Is national identity politics or culture? Is national identity rational or emotional? "China" is more inclined to a cultural concept than a political concept. The "country” under political Confucianism refers to Tianxia (天下), not China. It is difficult for us to see national identity in China's cultural, historical, and political aspects. Identity in ancient China emphasizes people's identity to polities and political operations under Confucian political ethics. As this conservative view of Tianxia (天 下) has completely broken in modern times, the Confucian view of state inevitably expands from the political field to various fields of Chinese elements, and only in this way can it better meet the needs of China's continuation and development. 
Regarding China's development in globalization, the concept of identity in the traditional Confucianism is unfavorable to the practice of modern national identity and nationalism. China does not just mean the existing Chinese territory. It represents the concept of the state with thousands of years of history, mind, and culture in China. The national identity for China is more inclined to the concept of Chinese essence rather than the concept of Chinese politicization. The nationalism in Confucianism is a common state ideal which shows the general will of the people and national interests. Although early Confucians see political boundaries as the basis for dividing the countries, they still yearn for the unification of the country with the unification of Chinese culture. When Qin Dynasty (秦朝) achieved China's unification, the concept of the state came into being. That is beyond the meaning of political unification. Chinese contemporary Confucian Mou Zongsan (牟宗三) believes that the ideal structure of a country with Confucianism should exist as a moral ration. In the process of moral practice, the realization of moral rationality must pass through the affirmation of the family and the state, before emerging into Tianxia (天 下) (Yingjie 2020). We can say that it is unrealistic to realize the ideals of the state without considering specific environmental development and the practice condition of moral rationality. Zhu Xi (朱喜)'s Four Books (四书) shows that when the country conflicts with the Tianxia (天下), individuals must choose the former, and abide by social ethics to make the country stable.

\section{Promote the development of contemporary democratic politics with the concept of confucian national "belonging-identity"}

\section{Incorporating national "belonging-identity" into ethical education}

The long history of nationalism illustrates that it can handle the relationship of interests and needs among individuals, families, and collectives. The state's special treatment for its nationals can strengthen the individual's sense of belonging and identification to the state. However, the blind emphasis on people's loyalty to the country can lead to a kind of Soviet socialist patriotism under certain conditions, which is contrary to personal and social-moral ethics and killing people's interests.

National "belonging-identity" in Confucianism is a moral national identity. The individual's sense of belonging and identification with the country is in line with social morality and personal moral development (Weber 2015). In Spring-Autumn and Warring States Period (春秋战国时期 chunqiuzhanguoshiqi), Confucians transcend the concept of borders of countries to describe a nation and incorporate the civilians of Tianxia (天下) into the blueprint of the country. This is the expression of "humanity" (仁 ren) in the political philosophy of Confucianism. The tributary system starting from Han Dynasty (汉朝) is the best evidence of the practice of nationalism and the national "belonging-identity" system in Confucianism. China guarantees surrounding countries' security and economic benefits by their admiration and obedience. Meanwhile, Confucian moral ethics in China and the surrounding countries have further strengthened such nationalism and identity. However, 
the Confucian national "belonging-identity" system that relies on strong national strength can easily collapse when facing more powerful external forces. Modern China is an example. The practice of national "belonging-identity" in contemporary Confucianism should rely on political civilization to realize the individual's rational judgment of national "belonging-identity". It can guide people to abide by the obligations to the state with moral and ethical requirements. Confucian national "belonging-identity" is a universal moral value, which does not promote the nationalism of China-centered. Instead, it guides countries influenced by Confucianism to establish a kind of moral and ideal nationalism (Kim 2013), thus ensuring the interactive implementation between individuals and the country.

\section{Deepening the influence and practice of national "belonging-identity" through culture}

The best way to achieve universal Confucian national "belonging-identity" is to deepen the influence of Confucian culture on individuals and society, enlightening and uniting people with culture, to realize the harmony between individuals and the country. Regaining Confucian culture can enhance the national self-confidence of the people and make people more confident in the country's development path. China's implementation of national identity under Confucian culture can achieve the rationality of political order to strengthen the rationalization of the political rule. This is not just to create a sense of national identity, but to create a Chinese-style national "belonging-identity" system and nationalism. National "belonging-identity" under Confucian culture is a major choice for China in the face of western countries' civilization and internationalization. Neo-nationalism promoted in contemporary China should get rid of the Confucian traditional fundamentals to pursue a kind of more pragmatic nationalism. National "belonging-identity" and nationalism in the Confucian culture are looking for the future direction of the mainstream culture of the country. So, China inevitably chooses the Confucian culture to support its national identity, to preserve and promote its national characteristics with China's unique national ideology and culture.

\section{Seeking change and in-variance under the national "belonging-identity" system}

We should improve Confucian national "belonging-identity" to solve the problems of political order and national development with Confucian "Supreme goodness," and apply it to the current state and social systems to lead the further development of a country.

The application and development of national "belonging-identity" in the political system should protect the individual's value in social life, including personal character, family relations, and personal behavior. So the Confucian nationalism must be "benevolent" (仁性 renxing) and rational. It should guide how individuals can achieve their full development and harmonious relationships with the country. Confucian national "belonging-identity" covers the family's ethical relationship and other basic kindness of society, such as social welfare (Tan et al. 2018). When 
people's "belonging" and "identity" to the country do not bring the corresponding protection of interests and rights for themselves, the one-way obligatory (people's duty to country) of national "belonging-identity" has no reciprocation for personal development. For the practice of national "belonging-identity" under Confucianism, it requires clear boundaries and balances of freedom and coercion to realize freedom under nationalism. Mencius (孟子) says that if the monarch makes a serious mistake, people have the right to overthrow him. Confucian national "belongingidentity" emphasizes harmony and adaptability, which can urge the government to listen to people's voices and meet their needs with multiple and open ideas. Confucian national "belonging-identity" also requires the individual's tolerance and obedience to national governance to make the relationship between the individual and the country at a moral level. To some extent, the liberalization of Confucian national "belonging-identity" is an important manifestation of democracy. It is necessary to realize its mandatory nature under the rule of law, legalizing the mutual commitment obligations between individuals and the state, to promote a logical "belongingidentity" system under Confucianism. This not only ensures people's obedience and adherence to the ruling order of the state, achieving an effective and stable state of national development, but also fulfill the state's obligations for protecting individual rights and interests, guiding the democratic process of the political system.

\section{Conclusion}

Confucianism uses moral relations to interpret the individual's belonging to the family, society, and the country. We should stress the moral nature of identity in Confucianism to make a country in a rational political order. National identity in contemporary China based on the Confucian "belonging" system can promote the practice of personal responsibility to the family and society and promote the moral and political practice of national identity. Although today's social environment differs from that of Confucianism, we can get some enlightenment from Confucian culture and political philosophy for the understanding of identity and country. We can the harmonious relationship among the individual, family, and the country through ethics, culture, and the art of governance. This is worth learning for the development of democratic politics in countries influenced by Confucian culture.

\section{Declarations}

Funding Open Access funding enabled and organized by Projekt DEAL.

Conflict of interest Not applicable.

Ethical statements No.

Data availability Not applicable.

Code availability Not applicable.

Author contributions The only author. 
Open Access This article is licensed under a Creative Commons Attribution 4.0 International License, which permits use, sharing, adaptation, distribution and reproduction in any medium or format, as long as you give appropriate credit to the original author(s) and the source, provide a link to the Creative Commons licence, and indicate if changes were made. The images or other third party material in this article are included in the article's Creative Commons licence, unless indicated otherwise in a credit line to the material. If material is not included in the article's Creative Commons licence and your intended use is not permitted by statutory regulation or exceeds the permitted use, you will need to obtain permission directly from the copyright holder. To view a copy of this licence, visit http://creativecommons.org/licen ses/by/4.0/.

\section{References}

Ames, Roger T. 2011. Epilogue: The Limits of Confucian Role Ethics. In Confucian Role Ethics: A Vocabulary, ed. R.T. Ames, 257-268. Beijing: The Chinese University of Hong Kong Press.

Bell, Daniel A. 2014. Reconciling Confucianism and Nationalism. Journal of Chinese Philosophy 41 (1-2): 33-54.

Kim, Sungmoon. 2013. To Become a Confucian Democratic Citizen: Against Meritocratic Elitism. British Journal of Political Science 43 (3): 579-599.

Tan, Chee Meng, Yoong Hon Lee, and Pek Kim Ng. 2018. National Identity and Social Welfare. Theoretical Economics Letters 08 (10): 1665-1673.

Weber, Ralph. 2015. Confucian Political Philosophy for Non-Confucians. Frontiers of Philosophy in China 10 (4): 547-567.

Yingjie, Guo. 2020. From Destruction to Reconstruction: China's Confucian Heritage, Nationalism, and National Identity. In The Heritage Turn in China: The Reinvention, Dissemination and Consumption of Heritage, ed. Carol Ludwig, Linda Walton, and Yiwen Wang, 89-110. Amsterdam: Amsterdam University Press. 